\title{
Estimating windthrow risk in balsam fir stands with the ForestGales model
}

\author{
by J.-C. Ruel ${ }^{1}$, C.P. Quine ${ }^{2}$, S. Meunier ${ }^{1}$ and J. Suarez ${ }^{2}$
}

Balsam fir (Abies balsamea (L.) Mill.) forests are inherently vulnerable to windthrow, especially when silvicultural treatments are applied. During recent years, it has become possible to model windthrow risk based on a good understanding of windthrow mechanics. In the present paper, the British ForestGales model has been adapted for balsam fir with data from a winching study in Quebec, Canada. This model calculates the threshold wind speed required to break or overturn the average tree in a stand and then calculates the probability of exceeding the threshold value. Modifications of the equations predicting crown characteristics and overturning resistance were introduced. The effects of age, site quality, wind exposure, thinning and the creation of new edges were assessed. The estimated critical wind speed for overturning and breakage decreases with age but the probability of damage remains low on sheltered sites. The creation of a new edge leads to an increased probability of damage, especially on exposed, highly productive sites. Thinning alone also increases the probability of damage and the magnitude of the increase varies with age and thinning intensity. On highly productive sheltered sites, the effect of thinning becomes especially important when thinning exceeds $35 \%$ of the number of stems or when stand age is greater than 70 years for a $35 \%$ thinning intensity. Thinning of new edges was also found to further increase the risk of windthrow on the most sheltered, high quality sites.

Les peupements de sapin baumier (Abies balsamea (L.) Mill.) sont, de façon inhérente, vulnérables au chablis, en particulier lorsque des traitements sylvicoles y sont appliqués. Au cours des dernières années, il est devenu possible de modéliser le risque de chablis sur la base d'une saine compréhension de la mécanique du chablis. Dans le présent article, le modèle Britannique ForestGales a été adapté pour le sapin baumier à partir d'une étude de treuillage réalisée au Québec. Ce modèle calcule la vitesse nécessaire à la rupture ou au déracinement de la tige moyenne d'un peuplement puis estime la probabilité que cette valeur soit dépassée. Des modifications ont été apportées aux équations prédisant les caractéristiques de la cime et la résistance au renversement. La simulation a porté sur l'effet de l'âge, de la qualité de station, de l'exposition au vent, de l'éclaircie et de la création de nouvelles lisières. Selon les simulations, la vitesse critique pour le bris ou le déracinement diminue avec l'âge mais la probabilité demeure faible pour les sites abrités. La création d'une nouvelle lisière a aussi conduit à une augmentation du risque de dommage, particulièrement sur les stations productives et exposées au vent. L'éclaircie seule a aussi augmenté le niveau de risque et cette augmentation était fonction de l'âge et de l'intensité d'éclaircie. Sur les stations abritées les plus productives, le risque est devenu particulièrement élevé lorsque l'intensité d'éclaircie était supérieure à $35 \%$ du nombre de tiges ou que l'âge était supérieur à 70 ans pour une éclaircie de $35 \%$. L'éclaircie de nouvelles lisières a conduit à une augmentation supplémentaire du risque de chablis sur les stations de bonne qualité les plus abritées.

\section{Introduction}

Balsam fir is an important commercial species that is widely distributed in eastern Canada. Forest dynamics of balsam fir are governed by the frequent occurrence of disturbances (Lortie 1979). The most important and most studied of these disturbances is defoliation by the spruce budworm (Choristoneura fumiferana Clem.) (Baskerville 1975, Blais 1983, Blais 1984, MacLean 1984, Blais 1985, Baskerville 1986). Studies of the factors associated with different levels of damage have made it possible to define interpretation keys that evaluate vulnerability of stands to the spruce budworm (Gagnon and Chabot 1990). Among the factors involved are stand composition and age, soil properties, region (Archambault et al. 1990, Dupont et al. 1991, Su et al. 1996, MacLean and MacKinnon 1997). This information is being incorporated in forest management planning (Québec 1994).

Other types of disturbance can also play a role in these forests. It would be useful, therefore, to develop similar tools to take their effect into account. Windthrow can be significant, especially when silvicultural operations are conducted (Hatcher 1961,

\footnotetext{
${ }^{1}$ Département des sciences du bois et de la forêt, Faculté de Foresterie et de Géomatique, Université Laval, Sainte-Foy, Québec G1K 7P4. E-mail: Jean-Claude.Ruel@sbf.ulaval.ca

${ }^{2}$ Forestry Commission Research Agency, Northern Research Station, Roslin, Midlothian, Scotland, U.K., EH25 9SY. E-mail: M.A.X.Gust@forestry.gov.uk
}

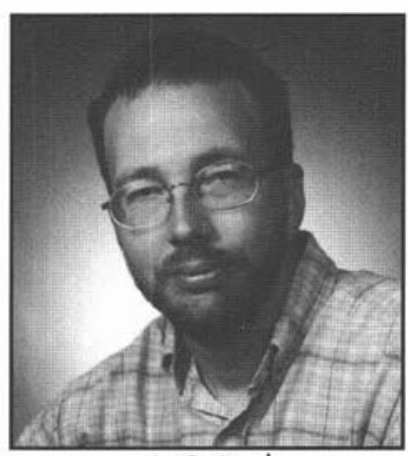

J.-C. Ruel

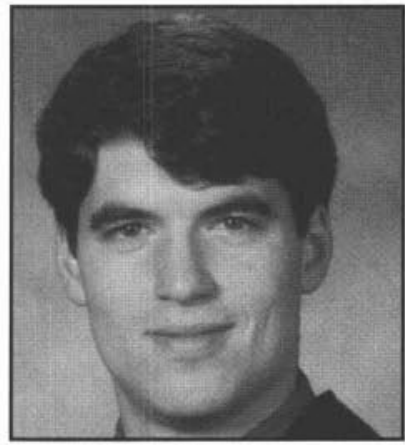

S. Meunier

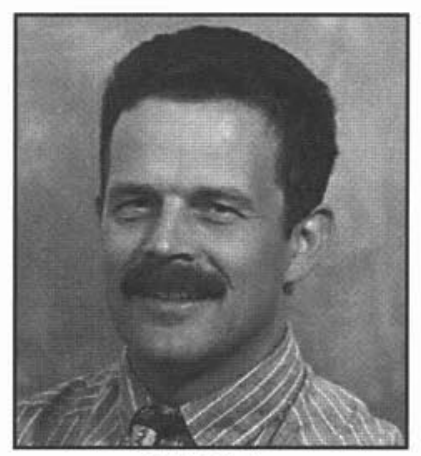

C.P. Quine

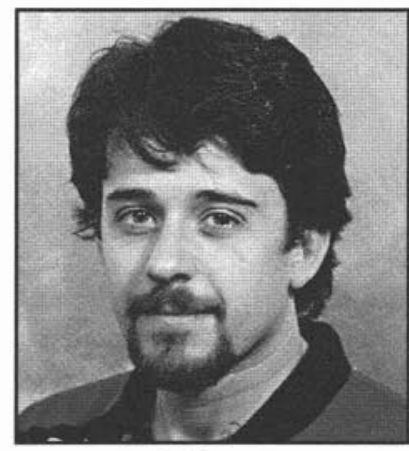

J. Suarez 
Holt et al. 1965, Vézina and Paillé 1969, Corriveau 1970). Windthrow hazard depends on the general wind climate and topography, as well as soil and stand characteristics. Partial cuttings or new edges of clearcuts are especially vulnerable. With an increased interest in partial cutting and the use of smaller clearcuts, windthrow hazard will probably become a more important concern in the near future (Franklin 1990, Laurance and Yensen 1991, Seymour and Hunter 1992, Esseen 1994).

A number of tools are available to assess windthrow hazard in forest management. Comprehensive reviews of the factors involved are available (Savill 1983, Ruel 1995, Nykanen et al. 1997). Interpretation keys, largely based on such information, have been proposed for some parts of Canada but they either are not adapted for balsam fir or do not take into account the whole set of influential factors (Meades and Moore 1989, Racey et al. 1989, Zelazny et al. 1989, Stathers et al. 1994, Mitchell 1995). Empirical models based on observed damage have been developed elsewhere but are not calibrated for balsam fir (Valinger et al. 1993, Valinger and Fridman 1997).

In recent years, it has become possible to model windthrow risk based on a good understanding of the mechanics of windthrow (Quine 1994, 1996). Some mechanistic models have been proposed for Europe (Peltola and Kellomaki 1993, Gardiner et al. 1999). These models calculate the threshold wind speed required to break or overturn the tree. They then estimate the wind speed and calculate the probability of exceeding the threshold value.

The aim of this paper is to model the risk of windthrow in balsam fir stands of eastern Canada located on mesic deep till sites using the ForestGales model. More specifically, we want to test the effect of age, site quality, wind exposure, thinning and the creation of new edges on the risk of windthrow. The ForestGales model has been selected for two main reasons: 1) it was the only one to have equations specific to fir species; and 2) the type of data potentially needed to tailor the model to balsam fir were available from an ongoing study.

\section{Methods \\ Brief description of the Forest model}

The ForestGales model was developed by the Forestry Commission to analyze windthrow risk for a number of tree species, although the data set for Sitka spruce (Picea sitchensis (Bong.) Carr.) is the most complete. The basic relationships included in the model were derived mainly from plantations and wind tunnel studies. A detailed description of the model has been presented by Gardiner et al. (1999).

The wind loading on a tree is calculated using the relationship between the drag of the air on a surface and the aerodynamic roughness of the surface. The mean force per tree is then calculated from the surface drag and the average space occupied by trees in the forest. Considering that this force is applied at the zero-plane displacement height, a mean bending moment can be calculated (Gardiner 1995). This mean bending moment can then be adjusted for the occurrence of gusts to estimate the maximum bending moment. The gust factor was established from wind-tunnel studies of the bending moments on model trees and is a function of spacing, height and distance to an edge (Gardiner et al. 1997). It varies from 4 at wide spacing ( $D=4$ $\mathrm{m})$ to 8 at a $1.75 \mathrm{~m}$ spacing. This bending moment can be multiplied by an edge factor to account for the tree position rel- ative to the edge. The edge factor was also derived from the wind tunnel experiments of Gardiner et al. (1997).

Calculation of the turning moment also considers the contribution of the overhanging mass once the tree position departs from the vertical. Displacement of the stem is calculated from the bending moment applied by the wind, Young's Modulus and the second moment of area of the cross-section following the method described by Wood (1995). From this displacement and the crown and stem mass calculated by the model, the additional turning moment is computed.

The resistance to breakage is based on the assumption that the wind-induced stresses in the outer fibres of the tree stem are constant at all points below the canopy (Morgan and Cannell 1994). This allows the stress to be calculated only at breast height. When this stress exceeds the modulus of rupture (MOR), the stem will break. The resistance to overturning is based on almost 2000 tree-pulling experiments. The best predictor variable for the overturning critical moment was stem weight. Regressions were forced through zero because, as stem weight approaches zero, so should the moment required to uproot it.

Given the critical bending moment calculated and the aerodynamic relationships included into the model, a critical wind speed can be calculated. This critical wind speed refers to the wind speed that is required to break or uproot the mean tree in the stand. To estimate the probability of damage, it is necessary to incorporate the wind climate. The range and mode for the extreme wind speed distribution are calculated from a DAMS (Detailed Aspect Method of [windiness] Scoring) score.DAMS is a method to estimate the total windiness of a site that has been proposed for Great Britain (Quine and White 1993). It combines scores for wind zone, elevation, topex and aspect. The wind zone score ( 2 to 13$)$ is read directly from a map of wind zones for Great Britain. The elevation score $(0$ to 10 ) is linearly derived from elevation up to $500 \mathrm{~m}$. The topex score $(0$ to 8.5$)$ is estimated from the sum of the eight principal compass point skyline angles. The aspect score incorporates the effect of slope orientation relative to dominant winds and the funnelling effect of the topography. Given the distribution of wind speeds associated with a DAMS value, the probability that the critical wind speeds will be exceeded within a year is calculated.

\section{Adapting the model to Eastern Canada}

To adapt the ForestGales model to eastern Canadian balsam fir stands, it was necessary to use unpublished data from a winching study. Winching was conducted on 41 balsam fir trees, ranging in dbh from 12 to $30 \mathrm{~cm}$ and in height from 11.8 to $19.2 \mathrm{~m}$. These trees were growing on deep mesic tills at the Montmorency forest of University Laval $\left(47^{\circ} 22^{\prime} \mathrm{N}, 71^{\circ} 07^{\prime} \mathrm{W}\right)$. Sites belong to site class I of Boudoux (1978). The methodology is generally similar to that of Silva et al. (1998). A pull is applied at tree mid-height with a mechanical winch. The force is measured during winching with a load cell. The tree is filmed during winching so that the position of the tree relative to the vertical can be determined when the maximum force is registered by the load cell. This position is then used to include the effect of gravity into the total turning moment. Detailed data on crown mass and form are gathered during the process.

Even though the British prototype model included balsam fir as a possible species to be simulated, many of the regres- 
Table 1. Mean wind speed of selected weather stations in Central Quebec

\begin{tabular}{lc}
\hline Station & Mean wind speed $\left(\mathbf{k m ~ h}^{-\mathbf{1}}\right)$ \\
\hline La Malbaie & 4.24 \\
Baie-Saint-Paul & 5.54 \\
Forêt Montmorency & 6.59 \\
Saint-Siméon & 8.58 \\
Notre-Dame-Des-Monts & 9.03 \\
Petite-Rivière-Saint-François & 10.66 \\
Saint-Hilarion & 10.84 \\
Les Éboulements & 13.58 \\
Isle-Aux-Coudres & 13.68 \\
Saint-Cassien-Des-Caps & 14.48 \\
Saint-Urbain & 14.52 \\
Grands-Fonds & 25.40
\end{tabular}

sions came from other fir species. Hence, crown width and length were predicted with values from noble fir (Abies procera $\mathrm{Rehd}$.):

$$
\begin{array}{lll}
\text { width }=12.25 * d b h+0.3306 & \mathrm{n}=17 & \mathrm{r}^{2}=0.56 \\
\text { length }=0.5205 * h+0.6119 & \mathrm{n}=17 & \mathrm{r}^{2}=0.59
\end{array}
$$

where $d b h$ is the diameter at breast height and $h$ is tree height, both expressed in $\mathrm{m}$.

The measured crown characteristics in the winching study were not represented adequately by the initial equations in the model. Although measured crown width agreed well with the model, crown length differed. The relationship for crown length in the winching study was highly significant $\left(r^{2}=0.48\right.$; $\mathrm{p}=0.0001$ ).

$$
\text { length }=-1.168+(0.637 * \text { height })
$$

However, the new equation created differences between measured and estimated crown biomass. To obtain proper estimates of this variable, crown density had to be raised from 2.5 to 2.63 . Wood density was reduced to reach a better agreement between measured and estimated stem biomass. The prototype values of modulus of rupture and modulus of elasticity also differed from those published by Jessome (1977) and so were replaced.

No reduction of stem strength due to the presence of knots is currently included in the model for balsam fir. In the absence of specific data, the original values for the knot factor were not modified. In the winching data that were used, only two trees snapped and they did so at about half of the stress that would be required assuming a knot factor of 1 . However, the critical wind speed for breakage obtained in simulations with a knot factor of 1 was lower than for overturning on site class I, whereas most of the winched trees were overturned. Thus, reduction of the knot factor did not seem appropriate, since it would lead to an even greater probability of breakage relative to overturning.

To estimate overturning resistance for balsam fir on freely drained soils, the model initially used regressions derived for grand fir (Abies grandis (Dougl. ex. D. Don) Lindl.) and noble fir:

$$
\text { Mcrit }_{\text {overt }}=180.01 * S W \quad \mathrm{r}^{2}=0.685 \mathrm{n}=18
$$

where Mcrit $_{\text {over }}$ is the critical moment for overturning and $S W$ is stem weight.

The relationship between stem biomass and resistive turning moment for trees from the winching study was highly significant (Equation [5]: $\mathrm{r}^{2}=0.92 ; \mathrm{p}<0.001$ ).

$$
\text { Mcrit }_{\text {overt }}=189.07 * S W
$$

Estimates based on this equation are relatively close to those obtained from equation [4] even though the species involved have been reported to differ in rooting characteristics. Grand fir possesses an adaptable root system, being able to develop a taproot on rather dry soils (Burns and Honkala 1990). Little seems to be known about the rooting habit of noble fir beyond the seedling stage but the species would appear to be at least moderately windfirm (Burns and Honkala 1990). In contrast, balsam fir is considered highly vulnerable and its roots are mostly confined to the duff layer and the first few centimetres of mineral soil, even though deeper rooting remains possible (Burns and Honkala 1990). Trees used in the winching study had a mean rooting depth of $56 \mathrm{~cm}$. The same equation was used for different site classes even though winching was conducted on sites belonging to site class I. The resistance to overturning on different site qualities should be tested since differences in soil characteristics are likely to be responsible for differences in productivity. The original equation [4] was thus replaced by the one derived from winching.

Simulations were performed with empirical yield tables for balsam fir of the boreal region (Boudoux 1978). These tables provide mean data of total number of stems, number of merchantable stems $(>9 \mathrm{~cm} \mathrm{DBH})$, height and diameter for an average natural stand. These data are available for ages ranging from 30 to 75 years on site classes I and II and from 30 to 100 years in site class III. The site quality classes included in these tables are based on the height reached at 50 years. Site classes I, II and III reach a height of 15,12 and $9 \mathrm{~m}$ respectively at age 50 . The simulations consider trees growing on a deep podzol with no cultivation and no drainage. Spacing was calculated assuming a square distribution of all trees and also for merchantable trees only $(\mathrm{dbh}>9 \mathrm{~cm})$.

To convert a critical wind speed into a probability of damage requires knowledge of wind speed distribution. The model uses a Weibull distribution associated to a DAMS score to estimate the probability of exceeding a given wind speed. In our simulations, we estimated a DAMS score based on the mean wind speed using an equation developed by the Forestry Commission:

$$
\text { DAMS }=3.56+\left(2.046 * \text { mean } \text { wind speed }\left(\mathrm{m} \mathrm{s}^{-1}\right)\right)
$$

This supposes that the distribution around this mean is similar between Great Britain and eastern Canada. Even though this should be investigated in more detail, comparison with a weather station of Eastern Canada for which the Weibull distribution was readily available (Walmsley and Morris 1994) shows that this assumption is not unreasonable. 

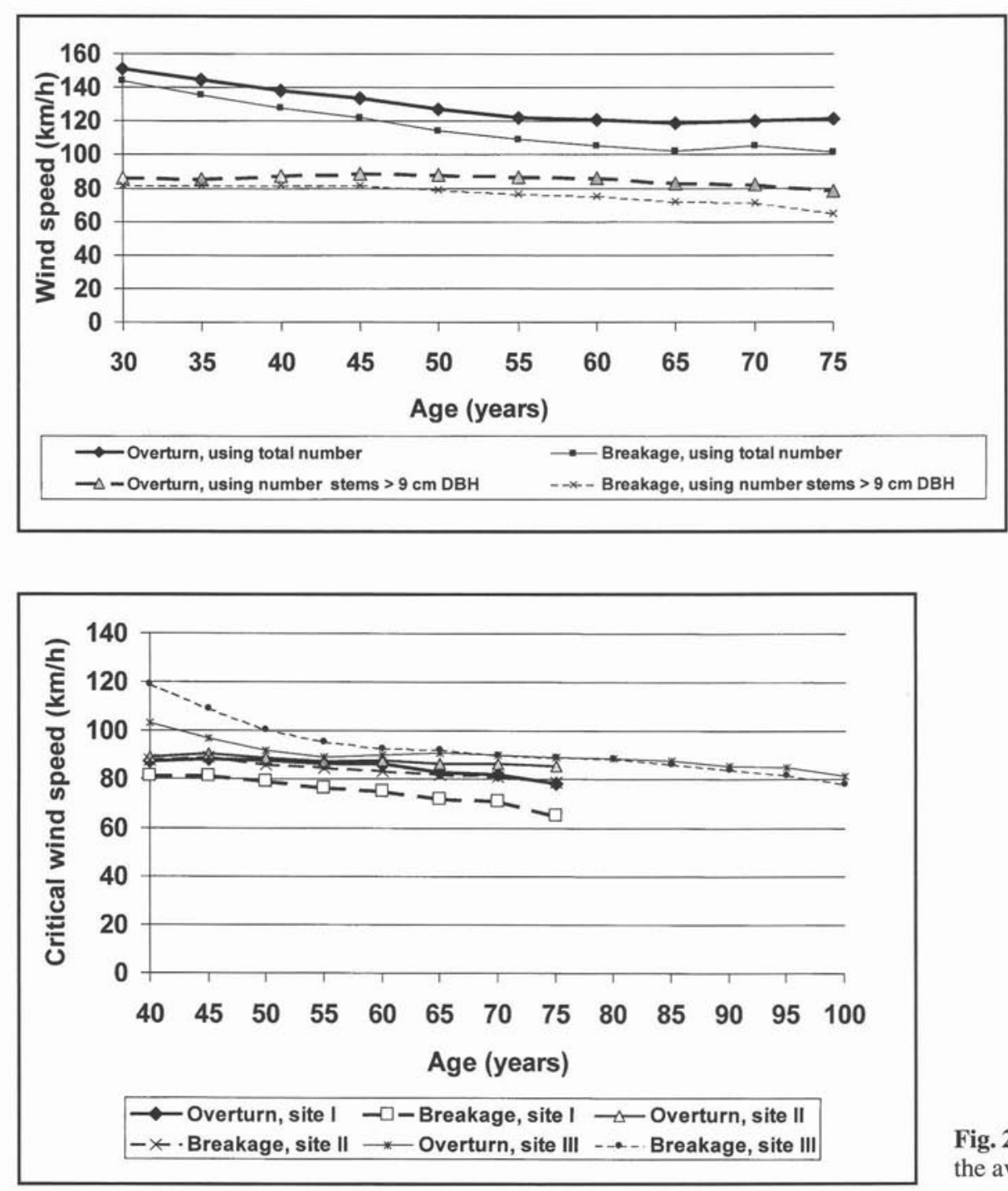

Fig. 1. Wind speed required to break or overturn the average tree in a stand, based on the total number and on the number of merchantable stems $(>9 \mathrm{~cm}$ $\mathrm{DBH}$ ) on site class I.
The annual mean wind speed in eastern Canada ranges from 10 to $25 \mathrm{~km} \mathrm{~h}^{-1}$, the highest value being for coastal areas of Nova Scotia and Newfoundland (Walmsley and Morris 1994). This range also corresponds well to the range of mean wind speeds inside a region of Quebec where a catastrophic windthrow occurred in 1994 (Table 1). Mean wind speeds of 10,15 and $25 \mathrm{~km} \mathrm{~h}^{-1}$ were therefore selected. As a result, DAMS values of 9,12 and 18 were used to represent the range of exposure at balsam fir sites in Eastern Canada.

\section{Simulating the effect of various silvicultural treatments}

First, evolution of windthrow risk was modelled for the different site indices without any silvicultural treatment. Secondly, the creation of a new edge was evaluated by adjusting the distance to a new edge in the model. In a third step, we tested the immediate effect of thinning by adjusting the spacing input into the model. The number of merchantable stems was reduced by 25,35 and $45 \%$ to simulate different thinning intensities. Since mean height and diameter were left unchanged, this could correspond to a free thinning. Free thinnings are especially appropriate for previously untreated natural stands like those that provided data for the yield tables (Smith et al. 1997). Finally, the combined effect of thinning and creation of a new edge was studied. This last simulation attempts to reproduce the current practice of thinning forest strips left along streams after clearcutting (Québec 1986). In order to compare it with a field study where a monitoring of windthrow has been conducted, a DAMS value of 7 , representative of valleys at the Montmorency Forest was selected.

\section{Results}

\section{Risk of damage for untreated stands}

Calculating the critical wind speed required to break or uproot the average tree gave quite different results depending upon whether the spacing was derived from the total number of stems or the number of merchantable stems $(>9 \mathrm{~cm} \mathrm{dbh})$ only. Critical wind speeds estimated from the number of merchantable stems were always lower than those obtained using the total number (Fig. 1). According to the simulation with the total number of stems, wind speeds of $105-120 \mathrm{~km} \mathrm{~h}^{-1}$ would be required to cause damage in 70 -year old stands whereas $71-82 \mathrm{~km} \mathrm{~h}^{-1}$ would be sufficient when the number of merchantable stems is used instead. The latter value seems to correspond better to the pattern of wind damage described by Ruel and Benoit (1999) who observed that nearly $60 \%$ of the area in 70 year old balsam fir stands was windthrown by wind speeds 


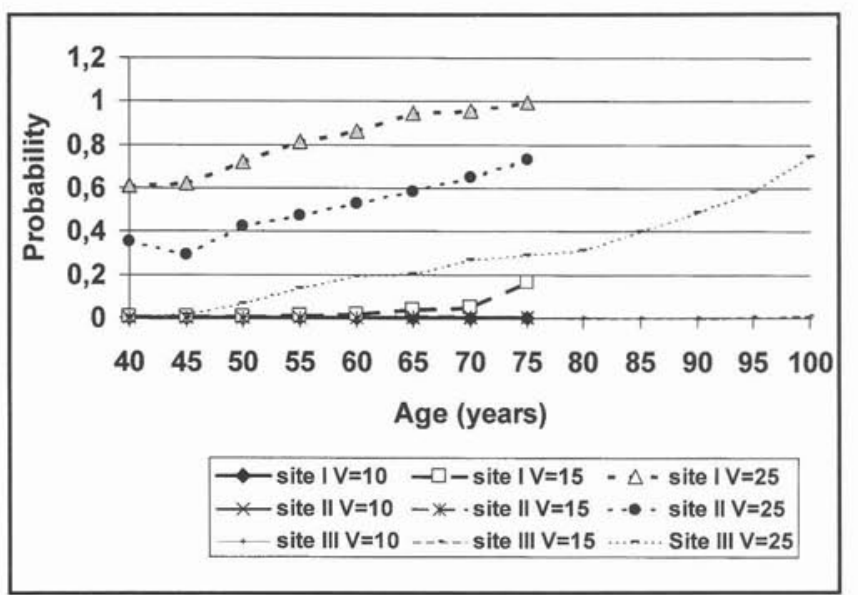

Fig. 3. Effect of mean annual wind speed $\left(\mathrm{V}=10,15\right.$ and $\left.25 \mathrm{~km} \mathrm{~h}^{-1}\right)$ and site quality on the probability of breakage.

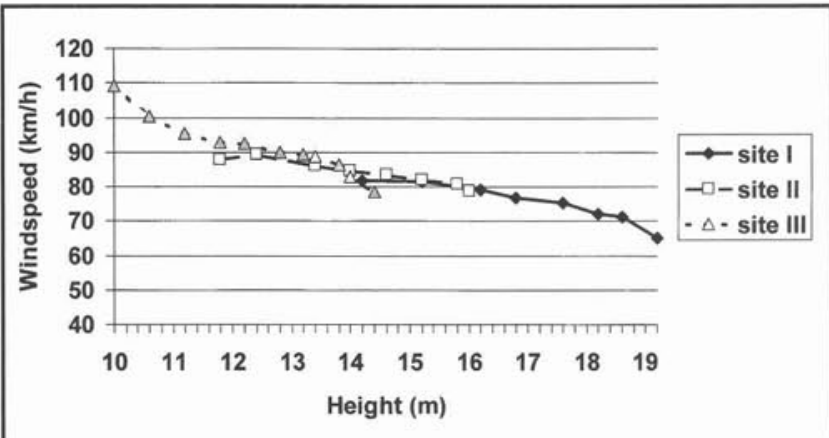

Fig. 4. Relationship between height and critical wind speed for breakage, by site quality.

between 55 and $65 \mathrm{~km} \mathrm{~h}^{-1}$ (Ruel and Benoit 1999). Since the size difference between merchantable and non-merchantable trees is small for stands less than 40 years of age, an adequate measure of spacing could not be easily identified and, therefore, young stands were not simulated.

An additional reason to use only the number of merchantable stems relates to the model structure. Selection of an adequate measure of spacing is of great importance since spacing is raised to the second power in some equations. The model calculates the bending moment from the surface drag caused by the canopy. Since non-merchantable trees would typically be intermediate and suppressed individuals, they would not significantly interact with the wind above the canopy. The studies used to derive the aerodynamic relationships were conducted in wind tunnels, with trees of relatively uniform size and spacing (Stacey et al. 1994, Gardiner et al. 1997). The approach developed gives a good approximation for even-aged regular stands but would probably need refinement for unevenaged or irregular stands.

Results from the simulation conducted for untreated stands show that the wind speed necessary to overturn or break the average tree in a stand decreases with age (Fig. 2). For a given age, the critical wind speed increases with decreasing site index. Except for young stands on site class III, the critical wind speed is lower for breaking than for overturning.

The probability of windsnap remained below 0.01 for any site quality class on sites corresponding to the lowest annu-

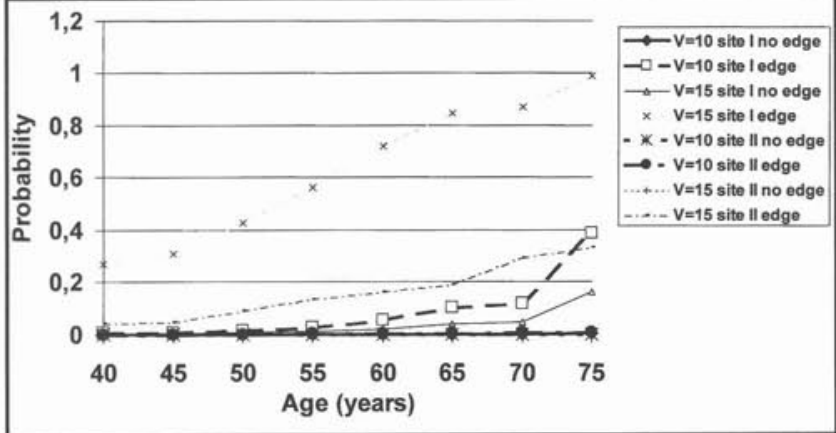

Fig. 5. Effect of exposing a new edge on probability of breakage, for different site classes and mean annual wind speeds $\left(\mathrm{V}=10\right.$ and $\left.15 \mathrm{~km} \mathrm{~h}^{-1}\right)$.

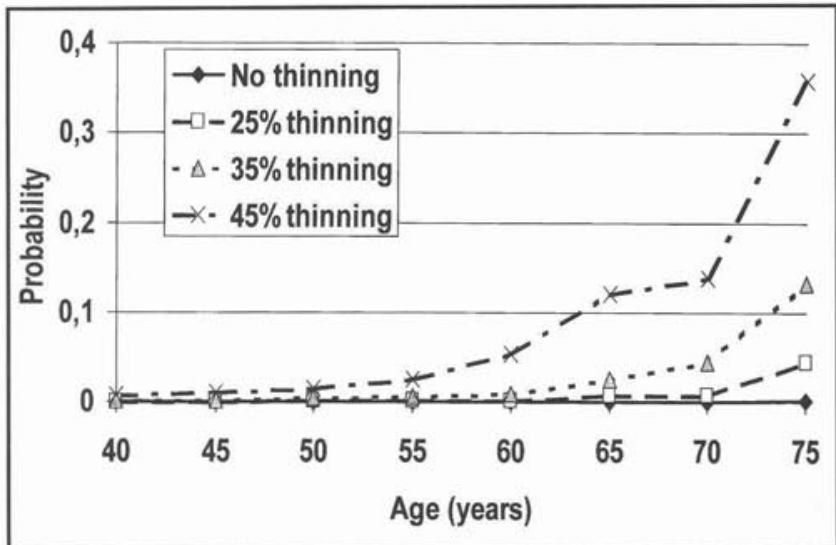

Fig. 6. Effect of thinning intensity on the probability of breakage on site class I (Mean annual wind speed of $10 \mathrm{~km} \mathrm{~h}^{-1}$ ).

al mean wind speed. However, for the intermediate wind speeds, the annual probability of damage on site class I increased slightly after 60 years and more importantly after 70 years (Fig. 3). On the most exposed sites, the probability of windsnap would be very high at 60 years for stands belonging to site classes I and II. For similarly exposed site class III sites, the probability of windsnap would increase steadily up to 100 years.

The effects of age and site class are closely related to stand height. When critical wind speeds are plotted against height, it can be seen that all three site classes behave quite similarly (Fig. 4).

\section{Effects of edge creation and thinning treatments}

The creation of a new edge greatly increased the probability of breakage for the average tree in stands belonging to site class I, even with a mean annual wind speed of $10 \mathrm{~km} \mathrm{~h}^{-1}$ (Fig. 5). On those sites, the annual probability of damage at a new edge increased to 0.10 at 65 years and reached 0.39 at 75 years. For these relatively sheltered sites, the probability of windsnap remained low for site class II even when a new edge was created. For more exposed sites, the creation of a new edge significantly increased the probability of windsnap for both site quality classes. For site class I, the probability of damage reached 0.27 at only 40 years.

Thinning also increased the probability of damage. When $25 \%$ of the stems were removed on sheltered site class 1 

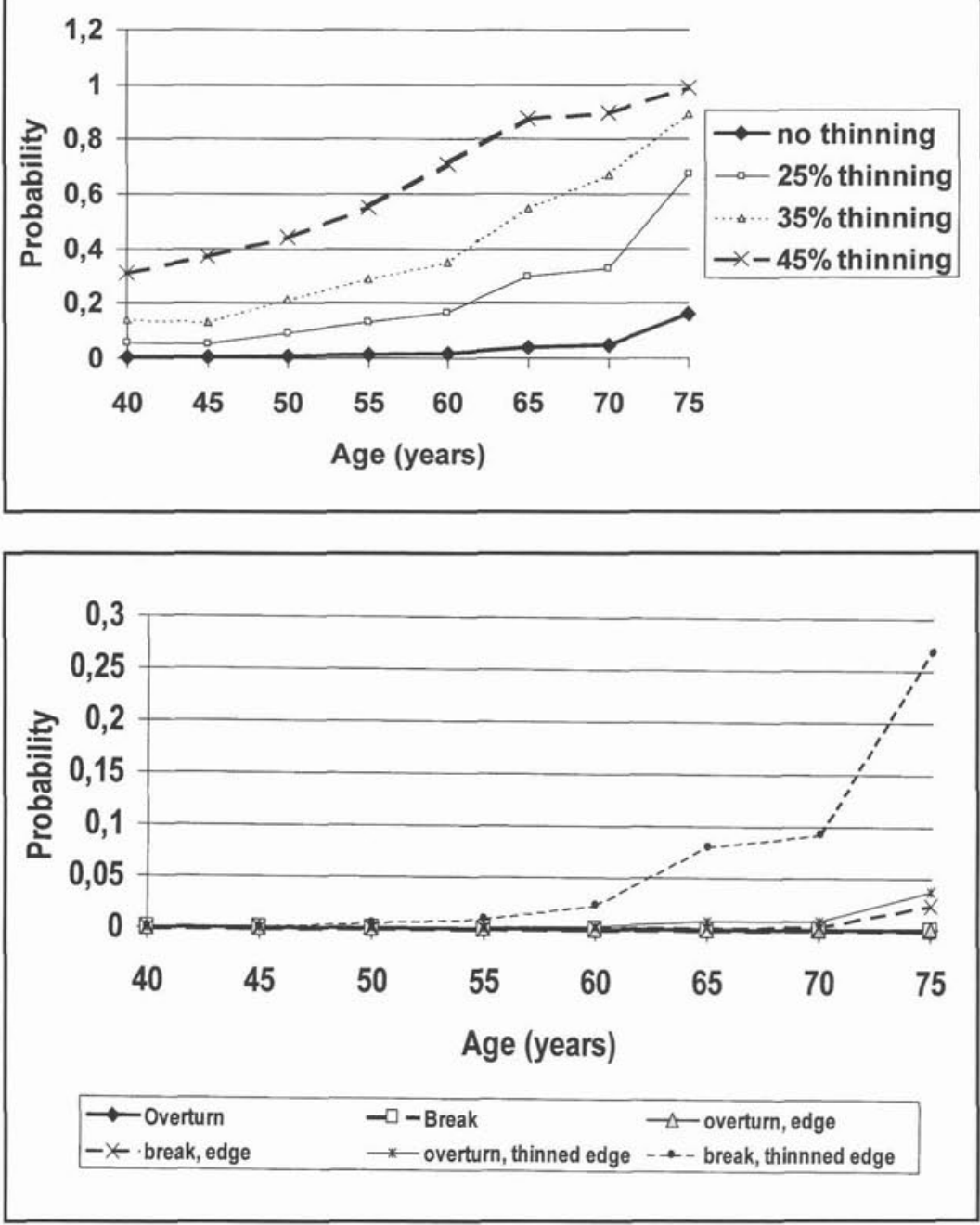

Fig. 7. Effect of thinning intensity on the probability of breakage on site class I (Mean wind speed of 15 $\mathrm{km} \mathrm{h}^{-1}$ ).
Fig. 8. Effect of thinning new edges on the critical wind speed on site class I (Mean annual wind speed of $7 \mathrm{~km} \mathrm{~h}^{-1}$ ). stands, the increased probability only became significant at 75 years (Fig. 6). The probability of damage increased with thinning intensity but this increase was greater between $35 \%$ and $45 \%$ than between 25 and $35 \%$. On more exposed sites (mean annual wind speed $=15 \mathrm{~km} \mathrm{~h}^{-1}$ ), even light thinning could lead to an increased probability of breakage (Fig. 7).

The combined effect of creating a new edge and thinning the remaining stand by removing $35 \%$ of the stems was also studied for more sheltered, site class 1 stands (mean annual wind speed $=7 \mathrm{~km} \mathrm{~h}^{-1}$ ). For these stands, thinning led to an additional increase in the probability of damage in comparison with unthinned edges (Fig. 8). Up to 60 years, the increase of the probability of damage remained low both for thinned and unthinned edges. At 65 years, the probability of damage went from almost nil in the untreated stand to 0.002 in the new edge and 0.08 in the thinned edge. At 75 years, the probability of damage reached 0.02 and 0.27 , respectively, for unthinned and thinned edges.

\section{Discussion}

The model results show that the critical wind speed for overturning and breakage of the mean tree in a stand decreases with age. The probability of damage remains low on sheltered sites but, on very exposed productive sites, the probability of breakage would be very high, even in young stands. For the very exposed, least productive sites, the probability of damage increased from 0.003 at age 40 to 0.202 at age 65 and 0.749 at age 100 . On sites with a mean annual wind speed of $15 \mathrm{~km}$ $\mathrm{h}^{-1}$, only stands belonging to site class I became prone to breakage in a significant manner, especially at 75 years. This agrees with results from Ruel and Benoit (1996), who have showed that the proportion of windthrown area in balsam fir stands was greater for stands 60 to 80 years old in comparison with younger stands.

Important differences between site classes were also seen but these can be attributed in the present case to different height growth rates. Hence, when the critical wind speed is examined in relation to height, no differences between site classes remain evident. Many other studies have found increased risk of windthrow with height (Elling and Verry 1978, Cremer et al. 1982, Smith et al. 1987, Peltola and Kellomaki 1993). The turning moment required to uproot or break a tree increases with height but the wind speed needed to produce this moment decreases with height (Peltola and Kellomaki 1993). However, it must be remembered that the same equation for resistance to overturning was used for all site classes, which probably accentuates the effect of height. In the meantime, it would seem possible to base windthrow hazard assessment on height since it integrates both age and site quality. 
The increasing vulnerability of balsam fir with age calculated by the model could even be underestimated for some regions, considering its tendency to develop high amounts of decay near rotation age (McClintock 1954, Basham 1992). In the present study, this tendency was not included since trees from the winching study contained only little decay near rotation age. This contrasts with results from Silva et al. (1998) who observed extensive decay even in externally sound balsam fir trees in western Quebec. This reflects the variation in amount of decay between regions and sites (Lavallée 1986, Whitney 1989, Basham 1992).

In general, the creation of a new edge also led to an increased probability of damage. Heavy damage around recent clearcuts has been observed elsewhere (Alexander 1967). The approaching airflow is forced upwards and edge trees become subjected to severe loadings (Fraser 1964, Stacey et al. 1994, Gardiner and Stacey 1996). For a mean annual wind speed of $15 \mathrm{~km} \mathrm{~h}^{-1}$, any new edge would seem to be at risk on the most productive sites. For site class II sites, the probability of damage would exceed 0.10 in new edges after age 50 . For a mean annual wind speed of $10 \mathrm{~km} \mathrm{~h}^{-1}$, the increase would only be significant on the best sites. There, probability of damage would rise from 0.028 to 0.10 between 55 and 65 years. Balsam fir stands in the boreal region (site classes I and II) reach their maximum annual mean increment in merchantable volume at 40 to 45 years (Boudoux 1978) so that they should normally be harvested before they reach 60 years, reducing the risk associated with new edges. However, retention of stands up to 60 years has been proposed in order to increase the proportion of sawlogs and improve the amount of advance growth (Coté and Bélanger 1991). Great caution should be taken when exposing new edges in balsam fir stands in instances where they are not protected by nearby topography. Another option would be to treat these edges to increase their resistance (Gardiner and Stacey 1996).

Thinning alone also increased the probability of damage. Thinning increases wind penetration into the stand and therefore the risk of windthrow (Busby 1965, Somerville 1980, Cremer et al. 1982, Savill 1983, Bouchon 1987, Ruel 1995, Gardiner et al. 1997). On sheltered sites, this increase was related to thinning intensity but it became especially important when thinning exceeded $35 \%$ of the number of stems. Heavy losses have been observed in thinned balsam fir stands, especially when thinning removed more than $40 \%$ of the basal area in 50 year-old stands (Hatcher 1961). Baldwin (1977) states that losses remained low when thinning removed up to $40 \%$ of the basal area in well-established balsam fir stands at the bottom of valleys. However, McClintock (1954) thinks that it would be unwise to harvest more than $25 \%$ of the basal area in spruce-fir stands. In our simulation, removing $35 \%$ of the stems in 50year old stands on sheltered site class I only led to a probability of damage of 0.015 . On sites with a mean annual wind speed of $15 \mathrm{~km} \mathrm{~h}^{-1}$, the probability of damage is increased by any thinning intensity.

The risk of damage after thinning also increases with age. For a thinning intensity of $35 \%$ on sheltered productive sites, this increase was particularly noticeable between 70 and 75 years. For sites with a mean annual wind speed of $15 \mathrm{~km} \mathrm{~h}^{-1}$, the probability was greater than 0.09 for any thinning intensity after 45 years. Heavy losses have been observed in thinned balsam fir stands, especially when stand age was greater than 70 years (Hatcher 1961). Our results suggest that thinning that removes up to $35 \%$ of the number of stems could be done on sheltered sites up to 65 years. On those sites, a thinning intensity of $45 \%$ should probably be restricted to stands not older than 55 or 60 years. Given the recommended rotation length, this leaves opportunities for commercial thinning and even for shelterwood cutting on those sites. However, on more exposed sites, thinning should probably be restricted to stands not older than 50 years and thinning intensity should remain low. It must also be emphasized that the simulation assumes that stands were previously untreated. The impact of juvenile spacing on the risk of damage should be studied.

Thinning new edges was also found to further increase the risk of windthrow on the most sheltered, high quality sites. Very little information regarding the effect of thinning new edges is available from the literature. Peltola (1996) estimated that stand density and height were the major factors influencing wind drag and turning moment of trees at clearcut margins. The turning moment decreased with increasing density, but the impact of height was greater than that of density. Ruel et al. (1999) have studied windthrow in riparian buffer strips, including some in which thinning was carried out. For stands of 50 to 70 years, no effect of thinning could be demonstrated. From our simulation, it can be seen than the effect of thinning might not be critical for stands less than 65 years old. The effect of thinning would be important thereafter. However, in the study of Ruel et al. (1999), the age range is not known precisely since 20 year-wide age classes were used. Moreover, age was estimated from aerial photographs and some differences in wind exposure existed. The authors concluded that these differences in wind exposure were more influential on the amount of damage than strip width or thinning. If we compare unthinned edges on sites with a mean annual wind speed of $10 \mathrm{~km} \mathrm{~h}^{-1}$ with thinned edges on sites with a mean annual wind speed of $7 \mathrm{~km} \mathrm{~h}^{-1}$, we see that the probability of breakage is rather similar between 60 and 75 years. This would support conclusions from the authors.

Different mean annual wind speeds have been used to cover the variability in wind climate over a wide region. These values can also be used to derive silvicultural guidelines in a management unit. In the Montmorency Forest, wind exposure has been studied in detail in a wind tunnel (Ruel et al. 1997, 1998). It was found that wind speed on hilltops would be about twice that in valleys. Since the weather station is located in one of the valleys, a mean annual wind speed of $7 \mathrm{~km}$ $\mathrm{h}^{-1}$ would describe the risk of damage in valleys. On hilltops, a value of $15 \mathrm{~km} \mathrm{~h}^{-1}$ would be representative. On mid-slopes, a value of $10 \mathrm{~km} \mathrm{~h}^{-1}$ could be used. In this manner, recommendations based on mean annual wind speed could be extended to landscape units. The suggestion by Fraser and Gardiner (1967) of determining a critical height on different topographic positions would seem an interesting approach.

\section{Conclusion}

The ForestGales model, with modifications to the region of application, represents a useful tool for simulating the risk of windthrow. Even though many assumptions remain to be verified, results were in accordance with empirical evidence. Further refinement of the model could be achieved by obtaining additional data representing resistive turning moment for other soil conditions, and canopy and stem dimensions for 
stands subjected to alternative silvicultural strategies. Wind behaviour should also be studied in natural stands, where the canopy structure is heterogeneous, and further characterisation of the extreme wind climate of forested areas in Eastern Canada should be done.

Results show an interesting potential for adjusting management activities on the basis of wind exposure. With a mean wind speed of $15 \mathrm{~km} \mathrm{~h}^{-1}$, any new edge would be at risk on productive sites, whereas the risk would only become significant after age 50 on medium sites. On less exposed sites, only the most productive sites would show an important risk of damage at 65 years. Thinning on exposed sites would be risky unless it is of low intensity and restricted to young stands. However, more sheltered sites offer many opportunities for thinning and even heavy thinning could be conducted in some cases. Thinning new edges has also been found to increase the risk of damage on very sheltered sites but the effect may not be apparent for some stand ages or when variations in wind exposure are present. The results provide interim guidance but further quantitative support for forest management could be provided by further modification of the model.

\section{Acknowledgements}

This work was carried out with financial support from HydroQuébec, Natural Sciences and Engineering Research Council and Université Laval. The ForestGales model and logistical support were provided by the Northern Research Station of the Forestry Commission, at Roslin, U.K.

\section{Bibliography}

Alexander, R.R. 1967. Windfall after clearcutting on Fool Creek. USDA For. Serv. RM-92. $11 \mathrm{p}$.

Archambault, R.R. Gagnon, G. Pelletier, M. Chabot and L. Bélanger. 1990. Influence du drainage et de la texture du dépôt sur la vulnérabilité du sapin baumier et de l'épinette blance aux attaques de tordeuse des bourgeons de l'épinette. Can J. For. Res. 20: 750-756. Baldwin, V.C. 1977. Regeneration following shelterwood cutting in a New Brunswick softwood stand. Can. For. Serv. Maritime Forest Research Centre, Inf. Rep. M-X-76.

Basham, J.T. 1992. Stem decay in living trees in Ontario's forests: a user's compendium and guide. Can. For. Serv. Great Lakes Forest Centre, Inf. Rep. O-X-421.

Baskerville, G.L. 1975. Spruce budworm: Super silviculturist. For. Chron. 51: 138-140.

Baskerville, G.L. 1986. Understanding forest management. For. Chron. 62: 339-347.

Blais, J.R. 1983. Trends in the frequency, extent, and severity of spruce budworms out breaks in eastern Canada. Can. J. For. Res. 13: 539-547.

Blais, J.R. 1984. Réflexions sur l'épidemiologie de la tordeuse des bourgeons de l'épinette (Choristoneura fumiferana (Clem) suite a 49 années d'études. Revue d'entomologie du Quebec 29: 27-39.

Blais, J.R. 1985. Epidemiology of the spruce budworm in western Ontario: a discussion. For. Chron. 61: 494-497.

Bouchon, T. 1987. État de la recherche relative aux dégats forestiers dûs aux tempêtes. Revue Forestière Française 39: 301-312.

Boudoux, M. 1978. Tables de rendement empiriques pour l'épinette noire, le sapin baumier et le pin gris au Québec, Gouvernment du Québec, Min. Terres et Forêts. 101 p.

Burns, R.m. and B.H. Honkala. 1990. Silvics of North America. USDA For.Serv., Agr. Handbook 654, Vol. 1 Conifers. 675 p.

Busby, J.A. 1965. Studies on the stability of conifer stands. Scottish For. 19: 86-102.

Corriveau, A. 1970. Effets de la tordeuse (Choristoneura fumiferana) sur de jeunes peuplements de sapin-épinette-bouleau blanc après coupe et après feu. Service Canadien des Forêts, Lab. Rech. For. Ste-Foy, Rapport d'information Q-F-X-8.

Côté, S. and L. Bélanger. 1991. Variations de la régénération préétablie dans les sapinères boréales en fonction de leurs caractéristiques. Can. J. For. Res. 21: 1752-1759.

Cremer, K.W., C.J. Borough, F.H. McKinnel and P.P. Carter. 1982. Effects of stocking and thinning on wind damage in plantations. N. Zeal. J. For. Sci. 12: 245-268.

Dupont, A., J. Bousquet and L. Bélanger. 1991. Relationships between balsam fir vulnerability to spruce budworm and ecological site conditions of fir stands in central Quebec. Can. For. Res. 21: 1752-1759. Elling, A.E. and E.S. Verry. 1978. Predicting wind-caused mortality in strip cut stands of peatland black spruce. For. Chron. 54: 249-252. Esseen, P.A. 1994. Tree mortality patterns after experimental fragmentation of an old-growth conifer forest. Biological Conservation 68: 19-28.

Franklin, J.F. 1990. The contribution of old-growth to the new forestry. University of Alberta, Forest Industry Lecture 24.

Fraser, A.I. 1964. Wind tunnel and other related studies on coniferous trees and tree crops. Scott. For 18: 84-92.

Fraser, A.I. and J.B.H. Gardiner. 1967. Rooting and stability in Sitka spruce. Forestry Commission, Bulletin 40. 28 p.

Gagnon, R. and M. Chabot. 1990. Principe et utilisation d'un système d'évaluation de la vulnérabilité des peuplements à la tordeuse des bourgeons de l'épinette. Opertations forestières sept/oct (1990).

Gardiner, B.A. 1995. The interactions of wind and tree movements in forest canopies. In M.P. Coutts and J. Grace (eds.). Wind and trees. pp. 41-59. Cambridge University Press, Cambridge.

Gardiner, B.A. and G.R. Stacey. 1996. Designing forest edges to improve wind stability. Forestry Commission, Northern Research Station, Technical Paper 16.

Gardiner, B.A., G.R. Stacey, R.E. Belcher and C.J. Wood. 1997. Field and wind tunnel assesments of the implications of respacing and thinning for tree stability. Forestry 70: 233-252.

Gardiner, B.H. Peltola and S. Kellomaki. 1999. The development and testing of models to predict the critical wind speeds required to damage coniferous trees. Ecological modeling (In press).

Hatcher, R.J. 1961. Partial cutting balsam fir stands on the Epaule River watershed, Quebec. Can. Dept. For., Res. Branch, Tech. Note. No. 105.29 p.

Holt, L., A. Linteau, P.H. Tremblay and W.L. Johnson. 1965. Some aspects of balsam fir management. Pulp and Paper Mag. Can.: WR322-WR338.

Jessome, A.P. 1977. Résistance et propriétés connexes des bois indegènes au Canada. Laboratoire des produits Forestiers de l'Est, Rapport Technique de Foresterie 21.

Laurance, W.F. and E. Yensen 1991. Predicting the impact of edge in fragmented habitats Biological Conservation 55: 77-92.

Lavallée, A. 1986. Les caries du sapin baumier dans le centre et le nord-est du Québec. Canadian Forest Service, Laurentian Forest Centre, Information Report LAU-X-70f.

Lortie, M. 1979. Arbres, forêts et perturbations naturelles au Québec. Presses de l'Université Laval. 172 p.

MacLean, D.A. 1984. Effects of spruce budworm outbreaks on the population and stability of balsam forests. For. Chron. 60: 273-279. MacLean, D.A. and W.E. MacKinnon. 1997. Effects of stand and site characteristics on susceptibility and vulnerablitiy of balsam fir spruce to spruce budworm in New Brunswick. Can J. For. Res. 27: 1859-1871.

McClintock, T.F. 1954. Factors affecting wind damage in selectivity cut stands of spruce and fir in Maine and Northern New Hampshire. USDA For. Serv. North. For. Exp. Stn., Station Paper No 70.

Meades, W.J. and J. Moore. 1989. A field guide to the Damman forest types of Newfoudland. Forest site classification manual. FDRA Report 003.

Mitchell, S.J. 1995. The windthrow triangle: a relative windthrow 
hazard assesment for forest managers. For Chron. 71: 446-450.

Morgan, J. and M.G.R. Cannell. 1994. Shape of tree stems: a reexamination of the uniform stress hypothesis. Tree Physiology 5: 63-74. Nykanen, M.L., H. Petola, C. Quine, S. Kellomaki and M. Broadgate. 1997. Factors affecting snow damage of trees with particular reference to European conditions. Silva Fennica 31: 193-213. Peltola, H. 1996. Model computations on wind flow and turning moment by wind for Scots pines along the margins of clear-cut areas. For. Ecol. Manage. 83: 203-215.

Petola, H. and Kellomaki, S. 1993. A mechanistic model for calculating windthrow and stem breakage of Scots pines at stand edge. Silva Fennica 27: 99-111.

Québec. 1986. Modalités d'intervention en milieu forestier. M.E.R. 75 p.

Québec. 1994. Une stratégie. Aménager pour protéger les forêts. Min. Ress. Nat., FQ94-3051.

Quine, C.P. 1994. An improved understanding of windthrow moving from hazard towards risk. Forestry Commission, Res. Inf. Note 257.

Quine, C.P. 1996. The chance of a windfall. Forestry and British Timber Aug. 1996: 17-19.

Quine, C.P. and I.M.S. White 1993. Revised windiness scores for the windthrow hazard classification: the revised scoring method. Forestry Commission, Res. Inf. Note 230.

Racey, G.D.. T.S. Whitfield and R.A. Sims. 1989 Northwestern Ontario forest ecosystem interpretations. Ont. Min. Nat. Res., NWOFTDU Tech. rep. 46 .

Ruel, J.-C. 1995. Understanding windthrow: silvicultural implications. For. Chron. 71: 443-445.

Ruel, J.-C. and R, Benoit. 1999. Analyse du chablis du 7 novembre 1994 dans les régions de Charlevoix et de la Gaspésie, Queebec, Canada. For. Chron. 75: 293-301.

Ruel, J.-C., D. Pin, L. Spacek, K. Cooper and R. Benoit. 1997. The estimation of wind exposure for windthrow hazard rating: Comparison between Stronblow, MC2, Topex and a wind tunnel study. Forestry 70: 253-256.

Ruel, J.-C., D. Pin and K. Cooper. 1998. Effect of topography on wind behaviour in a complex terrain. Forestry 71: 261-265.

Ruel, J.-C., D. Pin and K. Cooper. 1999. Windthrow in riparian buffer strips: Effect of wind exposure, thinning and strip width. For. Ecol. Manage. (In press)

Savill, P.S. 1983. Silviculture in windy climate. For. Abstracts, review article 44: 473-488.

Seymour, R.S. and M.L.J. Hunter. 1992. New forestry in eastern spruce-fir forests: Principles and applications to Maine. University of Maine.
Silva, G., J.-C. Ruel, M Samson and D. Pin. 1998. Influence de quelques défauts externes sur la résistance des arbres à une simulation mécanique de l'action du vent. Can. J. For. Res. 28: 123-131. Smith, D.M., B.C. Larson, M.J. Kelty and P.M. Ashton. 1997. The practice of silviculture: Applied forest ecology. John Wiley and Sons. 537 p.

Smith, V.G., M. Watts and D.F. James. 1987. Mechanical stablility of black spruce in the clay belt of northern Ontario. Can J. For. Res. 17: 1080-1091.

Somerville, A. 1980. Wind stability: Forest layout and silviculture. New Zeal. J. For. Sci. 10: 476-501.

Stacey, G.R., R.E. Bekcher, C.J. Wood and B.A. Gardiner. 1994 Wind flows and forces in a model spruce forest. Boundary-layer meterology 69: 311-334

Stathers, R.J., T.P. Rollerson and S.J. Mitchell. 1994. Windthrow handbook for British Columbia forests. B.C. Min. For., Working Paper $9401.31 \mathrm{p}$.

Su., Q., D.A. MacLean and T.D. Needham. 1996. The influence of hardwood content on balsam fir defoliation by spruce budworm. Can. J. For. Res. 26: 1620-1228.

Valinger, E. and J. Fridman. 1997. Modeling probablitiy of snow and wind damage in Scots pine stands using tree characteristics. For. Ecol. Manage. 97: 215-222.

Valinger, E.L., Lundqvist and L. Bondesson. 1993. Assessing the risk of snow and wind damage from tree physical characteristics. Forestry. 66: 249-260.

Vézina, P.E. and G. Paillé. 1969. Améngement intensif des sapiniéres mûres et surannées à la Forêt Montmorency. Fonds de recherches forestiéres de l'université Laval, contribution no 14.48 p.

Walmsley, J.L. and R. Morris. 1994. Cartes des resources énergie éolienne au Canada. Canada, Service de l'Environnement Athmosphérique, ARD-92-003-F.

Whitney, R.D. 1989. Root rot damage in natural regenerated stands of spruce and balsam fir in Ontario. Can. J. Res. 19: 295-308.

Wood, C.J. 1995. Understanding wind forces on trees. In M.P. Coutts and J. Grace (eds.). Wind and trees. pp. 133-164. Cambridge University Press, Cambridge.

Zelany, V.F., T.T.M. Ng, M.G. Hayter, C.L. Bowling and D.A. Bewick.1989. Field guide to forest site classification in New Brunswick. Harvey-Harcourt-Fundy Site Regions. New Brunswick Dept. Nat. Res. and Energy. 43. p. 